\title{
IMPROVING THE QUALITY OF BEEF BURGERBY ADDING THYME ESSENTIAL OIL AND JOJOBA OIL
}

\author{
ADICIÓN DE ACEITE ESENCIAL DE TOMILLO Y ACEITE DE JOJOBA PARA MEJORAR \\ LA CALIDAD DE LA HAMBURGUESA DE VACUNO
}

\author{
Kassem, G.M. ${ }^{1}$, Atta-Alla, O.A. ${ }^{1}$ and Ali, F.H.M. ${ }^{2 *}$ \\ ${ }^{1}$ Department of Food Hygiene. Faculty of Veterinary Medicine Cairo University. Cairo, 12123. Egypt. \\ ${ }^{2}$ Department of Food Hygiene. Faculty of Veterinary Medicine Beni-Suef University. Beni-Suef 62511. \\ Egypt. *fatma111969@yahoo.com
}

\section{AdDITIONAL KEYWORDS \\ Natural antimicrobials. Natural antioxidants.}

\section{SUMMARY}

Essential oils and their components are becoming increasingly popular as naturally occurring antimicrobial and antioxidant agents. Therefore, the present study aimed to investigate the effect of addition of different concentrations $(0.02,0.04,0.06 \%)$ of essential oil of thyme (TEO) and $0.1 \%$ oil of jojoba (JO) on the quality and stability of beef burger. The obtained results indicated that the best sensory quality was attained at the highest TEO concentration $(0.06 \%)$, while slight improvement in sensory quality was noticed in samples treated with $\mathrm{JO}(1 \%)$ as compared with control samples. The storage time significantly affected the TBA (thiobarbituric acid) values, as treated samples with TEO and JO showed lower values of TBA compared with the control samples. Regarding to microbial load, samples treated with 0.04 and $0.06 \%$ of TEO revealed significant reduction at $12^{\text {th }}$ day of storage as compared with the control samples. On the other hand, the obtained results illustrated that $\mathrm{JO}$ have no significant effect on the microbial load.

\section{RESUMEN}

Los aceites esenciales y sus componentes, son cada vez más populares como agentes antimicrobianos y antioxidantes existentes naturalmente. Por ello, el presente trabajo se centró sobre el efecto de la adición de diferentes concentraciones de aceite esencial (EO) de tomillo $(0,02$; $0,04 ; 0,06 \%)$ y aceite $(0)$ de jojoba $(0,1 \%)$ sobre

Recibido: 17-12-09. Aceptado: 29-3-10.

\section{Palabras CLAVE ADICIONALES}

Antimicrobianos naturales. Antioxidantes naturales.

la calidad y estabilidad de hamburguesas de ternera. Los resultados obtenidos indican que la mejor calidad sensorial fue conseguida con la mayor concentración de EO de tomillo $(0,06 \%)$ mientras que solamente un débil aumento de la calidad sensorial fue registrado en las muestras tratadas con $\mathrm{O}$ de jojoba (1\%) cuando se compararon con las muestras control. El tiempo de almacenamiento afectó significativamente a los valores de TBA (ácido tiobarbitúrico) mientras que las muestras tratadas con EO de tomillo y $\mathrm{O}$ de jojoba, mostraron valores más bajos que los controles. Con referencia a la carga microbiana las muestras tratadas con 0,04 y $0,06 \%$ de EO de tomillo, revelaron una reducción significativa con respecto al control en el día 12 de almacenamiento. Por otra parte, los resultados obtenidos ilustran que el $\mathrm{O}$ de jojoba no tiene efecto significativo sobre la carga microbiana.

\section{INTRODUCTION}

Modern trends towards production of pre-cooked, refrigerated ready-to-eat meat products have made the control of lipid oxidation increasingly important. Processed meats which are minced and cooked are susceptible to accelerate lipid oxidation, which is one of the main factors responsible for loss of quality of meat products besides microbiological deterioration (Rhee, 1989; 
and Singh, 1996). Therefore, much attention in recent years has been focused on the use of extracts from herbs and spices to improve sensory characteristics, retard lipid oxidation and extend the shelf life of meat products (Arora and Kaur, 1999; Gulluce et al., 2003 and Lagouri and Nisteropoulou, 2009).

The antimicrobial activity of plant oils and extracts has formed the bases of many applications, including processed meat preservation, pharmaceuticals, alternative medicine and natural therapies (Akgül and Kivanç, 1988; Jones, 1996; Reynolds, 1996; Lis-Ba and Deans, 1997; Elgayyar et al., 2001; Mejlholm and Dalgaard, 2002; Kalemba and Kunicka, 2003).

Thyme is traditionally used as flavouring agents in meat and meat products (Mishra and Dube 1994; Lawless, 1995). Recently, its essential oil is known to include carvacol, borneol, geraniol, but most importantly, thymol. Thyme essential oil also contains a variety of flavonoids, including apigenin, naringenin, luteolin and thymonin (StahlBiskup, 1991; Senatore 1996; Peñalver et al., 2005). These flavonoids increase thyme antioxidant capacity (Lacroix et al., 1997). The volatile oil components of thyme have also been known to have antimicrobial activity against different bacteria and fungi species (Dorman and Deans 2000; Nguefack et al., 2009). Staphalococcus aureus, Bacillus subtilis, Escherichia coli and Shigella sonnei are among bacterial species against which thyme has been shown to have antibacterial activity (Kim et al., 1995 and Smith-Palmer et al., 1998). In this regard Soliman and Badeae (2002) and Kalemba and Kunicka (2003) found that thyme essential oil $(500 \mathrm{ppm})$ in vitro possess strong antimicrobial properties towards food born bacteria and fungi, including Aspergillus flavus, A. parasiticus, A. ochracus and Fusarium moniliforme. Although essential oils are well documented in vitro as natural antimicrobial, some food components decrease the antimicrobial effects of the essential oil (Sofos et al., 1998; Lopez-Malo et al., 2000; Nychas and Tassou 2000).

Jojoba oil is the liquid wax produced in the seed of the jojoba (Simmondsia chinensis) plant. The oil makes up approximately $50 \%$ of the jojoba seed by weight (Salgm, 2007). It is a straight chain wax ester of 36 to 46 carbon atoms in length. Each molecule consists of a fatty acid and a fatty alcohol joined by an ester bond (Miwa, 1971; Wisniak, 1994; Saguy et al., 1996). Jojoba oil is not affected by prolonged storage or changes in temperature when compared with other vegetable oils, nor does it facilitate microbial growth (Miwa, 1971 and Wisniak, 1994). Nowadays, there has been renewed interest in its food potential as a vegetable and salad oil and shortening (Kalscheuer et al., 2006).

The questions concerning the safety of synthetic food additives have encouraged an increase interest in the use of natural substances and request more detailed studies of plant resources and essential oils (Kalemba and Kunicka, 2003). Therefore, the objective of this study was to evaluate the effectiveness of TEO and JO for controlling sensory, physico-chemical and microbiological quality of beef burger during two weeks of refrigeration storage at $5^{\circ} \mathrm{C}$.

\section{MATERIALS AND METHODS}

\section{EXTRACTION OFTEO}

Extraction had been done in the Department of Biochemistry, Faculty of Agriculture, Cairo University, by hydrodistillation of dried plant leaves followed by evaporation under vacuum according to Cosentino et al. (1999). While JO was obtained by direct extraction of jojoba seeds without refining.

\section{BEEFBURGERPRODUCTION}

Was carried out in agreement with Egyptian standard specification for burger (ESS 1688/1991) as follows: Twenty kilo- 


\section{EFFECTS OF THYME ESSENTIAL OIL AND JOJOBA OIL ON BEEF BURGER QUALITY}

grams of freshly beef chuck 24 hours postmortem was purchased from local butcher shop at Giza market-Egypt and directly transported to the laboratory in an ice box to be minced in electrical mincer $(4 \mathrm{~mm})$. Minced meat $65 \%$, fat $20 \%$, soybean $5 \%$, black pepper $0.3 \%$, salt $1.8 \%$ and water $10 \%$ were thoroughly mixed for five minutes and divided into five portions. First portion was used as control, while the other portions were eithermixed with TEO $(0.02,0.04,0.06 \%)$, or jojoba oil $(0.1 \%)$, respectively. The obtained pastes were formed into $50 \mathrm{~g}$ beef burger using cardboard meat box, packed in foam plates and stored at refrigerator shelf at $5^{\circ} \mathrm{C}$. Three samples for each treatment were examined every three days for two weeks as follows:

\section{SENSORY QUALITY}

Odour, colour and overall acceptability of raw beef burger samples were assessed by 5-7 members of Food Hygiene and Control Department (with past experience in burger processing and evaluation) to evaluate their sensory characteristics. Sensory hedonic scheme, ranged from 0 (very bad) to 8 (very good) following the procedures of AMSA (1995), was applied.

\section{PhysiCO-CHEMICAL CHARACTERISTICS}

Thiobarbituric acid (TBA)-value (mg malonaldehyde (mal)/kg) was estimated by distillation technique using 2- thiobarbituric acid $0.02 \mathrm{M}$ (Sigma Chemical Co. Ltd USA as described by FAO (1986).

pH determination: $10 \mathrm{~g}$ of each sample were homogenized with $20 \mathrm{ml}$ of distilled water and $\mathrm{pH}$ value was determined using pH meter (Suntex-T-s-1 911005942/ Taiwan) with calibrated probe type (Ingold 406-M6DXk-S7/25), according to Dzudie etal. (2004).

\section{MICROBIOLOGICAL QUALITY}

Samples homogenate and serial decimal dilutions were prepared following the recommendation of Spencer and De Spencer (2001). The serial dilutions of each sample were investigated for count of Enterobacteriacae on violet red bile dextrose agar, Staphylococci on Barid Parker agar, total mould on Saboureaud dextrose agar, proteolytic bacteria using $10 \%$ skim milk agar and lipolytic bacteria using tributyrine agar applying the techniques described by APHA (1992).

\section{STATISTICALANALYSIS}

The results are presented as the mean of three replicates with standard deviation. The data generated were analyzed by statistical software package using standard procedures for analysis of variance and Duncan multiple range test (Duncan, 1955) to compare the means and determine the effect of treatments (SAS, 1995). The probability value of $p \leq 0.05$ was used as the criteria for significant differences.

\section{RESULTSANDDISCUSSION}

\section{SENSORYEVALUATION}

Figure 1 represents odour, colour and overall acceptability values for all examined samples for the first three days of storage. Decline of sensory attributes begin after the third day of storage with marked reduction of odour, colour and overall acceptability values in the control samples at the $6^{\text {th }}$ day with rejectionable characteristics at the $9^{\text {th }}$. While TEO treated samples revealed acceptability for 12 and 15 days for $0.02 \%$ and $0.04,0.06 \%$ respectively.

It is worth to mention that significant improvement of odour and overall acceptability of investigated samples were observed at 0 day due to addition of thyme essential oil, this could be referred to its aromatic effect (Mishra and Dube, 1994; Lawless, 1995). Furthermore, highest concentration $(0.06 \%)$ TEO treated samples showed the best sensory quality. On the other hand, a noticed improvement in sensory characteristics could be noticed in samples treated with jojoba oil as compared with control samples. Addition of TEO and 
KASSEM, ATTA-ALLAAND ALI

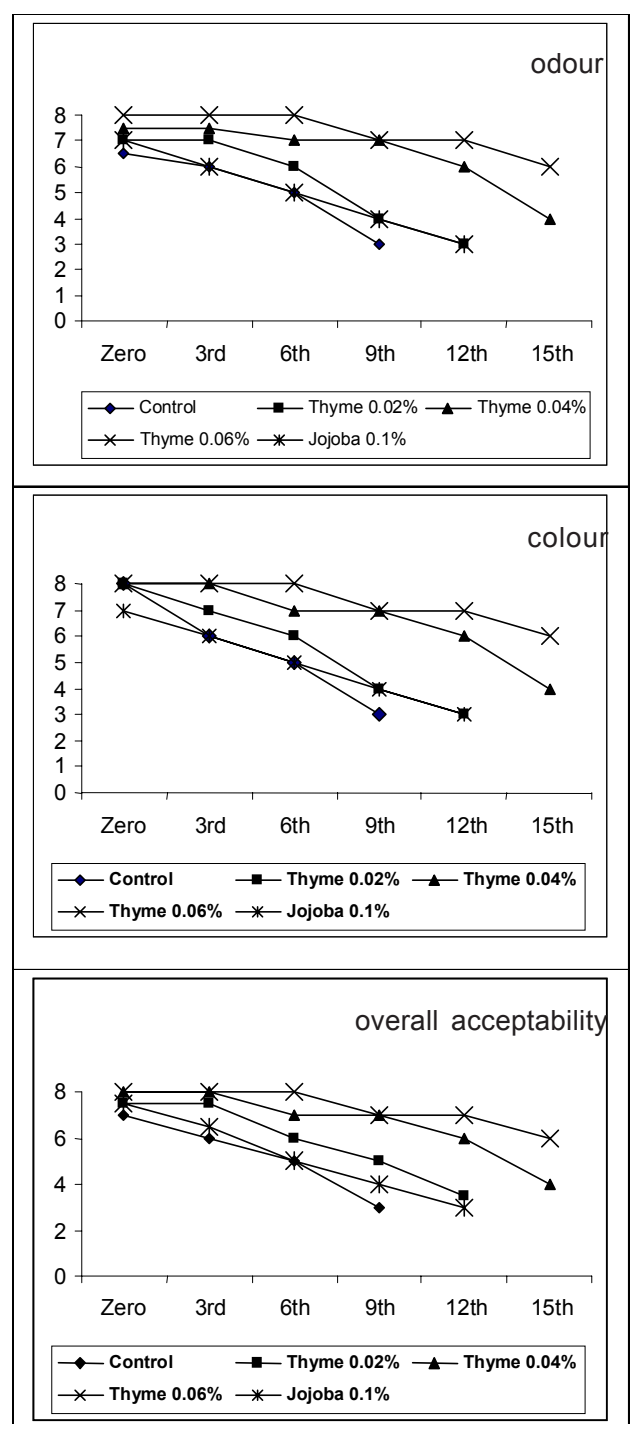

Figure 1. Changes in burger characteristics during storage period. (Cambios en las características de las hamburguesas durante el almacenamiento).

JO to beef burger formulation showed extension storage time than control samples by three days for TEO $(0.02 \%)$ treated samples and JO $(0.1 \%)$ and five days for
TEO $(0.04,0.06 \%)$ treated samples with highest odour, and overall acceptability value for $0.06 \%$ TEO treated samples.

\section{TBA-VALUE}

TBA-value is a valuable test in determination of lipid oxidation(Pikul et al., 1983). Table I indicates gradual increase of TBAvalues of all examined samples during storage time. No significant difference $(\mathrm{p} \leq 0.05)$ were observed among treated samples and control at $0 \mathrm{~d}$, which indicates that oxidative deterioration of beef burger lipid occurred during storage time.

At the third day of storage significant reduction $(\mathrm{p} \leq 0.05)$ of TBA-values of TEO and JO treated beefburger samples was obvious. Moreover, an inverse trend was observed with addition of TEO, where, the lowest TBA-values were recorded in samples containing $0.06 \%$ followed by 0.04 and respectively. Such findings may be attributed to the high antioxidant effect of TEO, which is related to the scavenger nature of its flavonoids and phenolic content as apigenin, naringenin, luteolin, thymonin, carvacrol and thymol (Stahl- Biskup, 1991; Senatore, 1996; Lacroix et al., 1997; Peñalver et al., 2005; Skerget et al., 2005; Wojdylo et al., 2007 and Amarowicz et al., 2009).

Regarding JO treated beef burger, TBAvalues were significantly lower those than from control samples. These values were however significantly higher than samples treated with 0.04 and $0.06 \%$ TEO.

In contrast the JO proved weak antioxidant effect which is referred to its molecular stability (Miwa, 1971 and Wisniak, 1994).

It's worth to mention that at the $12^{\text {th }}$ day of storage both $0.02 \%$ TEO and Jojoba oil treated samples showed TBA-values over $0.5 \mathrm{mg} \mathrm{mal} / \mathrm{kg}$ which rendered these samples unacceptable.

\section{$\mathrm{PH}-\mathrm{VALUE}$}

$\mathrm{pH}$-value of examined samples reveals that no significant difference $(\mathrm{p} \leq 0.05)$ could be established among treated beef burger 


\section{EFFECTS OF THYME ESSENTIAL OIL AND JOJOBA OIL ON BEEF BURGER QUALITY}

Table I. TBA-values in mg malonaldehyde/kg of examined samples. (Valores de TBA en mg de malonaldehido/kg de muestra analizada).

\begin{tabular}{cccccc}
\hline $\begin{array}{l}\text { Period } \\
\text { (days) }\end{array}$ & Control & Thyme 0.02\% & $\begin{array}{c}\text { Treatment } \\
\text { Thyme 0.04\% }\end{array}$ & Thyme 0.06\% & Jojoba 0.1\% \\
\hline 0 & $0.257 \pm 0.009$ & $0.257 \pm 0.009$ & $0.257 \pm 0.009$ & $0.257 \pm 0.009$ & $0.257 \pm 0.009$ \\
3 & $0.298 \pm 0.011^{\mathrm{a}}$ & $0.271 \pm 0.010^{\mathrm{b}}$ & $0.264 \pm 0.010^{\mathrm{b}}$ & $0.261 \pm 0.009^{\mathrm{b}}$ & $0.264 \pm 0.010^{\mathrm{b}}$ \\
6 & $0.495 \pm 0.018^{\mathrm{a}}$ & $0.323 \pm 0.012^{\mathrm{bc}}$ & $0.302 \pm 0.011^{\mathrm{c}}$ & $0.274 \pm 0.010^{\mathrm{d}}$ & $0.349 \pm 0.013^{\mathrm{b}}$ \\
9 & $0.712 \pm 0.026^{\mathrm{a}}$ & $0.420 \pm 0.015^{\mathrm{c}}$ & $0.325 \pm 0.012^{\mathrm{d}}$ & $0.318 \pm 0.011^{\mathrm{d}}$ & $0.488 \pm 0.018^{\mathrm{b}}$ \\
12 & $0.930 \pm 0.033^{\mathrm{a}}$ & $0.511 \pm 0.018^{\mathrm{c}}$ & $0.386 \pm 0.014^{\mathrm{d}}$ & $0.344 \pm 0.012^{\mathrm{e}}$ & $0.553 \pm 0.020^{\mathrm{b}}$ \\
15 & $1.220 \pm 0.044^{\mathrm{a}}$ & $0.670 \pm 0.024^{\mathrm{b}}$ & $0.422 \pm 0.015^{\mathrm{c}}$ & $0.376 \pm 0.014^{\mathrm{c}}$ & $0.626 \pm 0.023^{\mathrm{b}}$ \\
\hline
\end{tabular}

abln a row, means with similar letters are not significantly different at $p \leq 0,05$.

Each value represents the mean \pm S.D.

during all storage time. Where $\mathrm{pH}$ of control, $0.02 \%$ TEO, $0.04 \%$ TEO $0.06 \%$ TEO and JO were $6.53 \pm 0.23,6.38 \pm 0.23,6.27 \pm 0.22$, $6.26 \pm 0.22$ and $6.33 \pm 0.22$ respectively at $12^{\text {th }}$ day of storage. Such finding could be referred to the low quantity of oil added in the burger formulation and due to buffering effect of meat (Djenane et al., 2004).

\section{MICROBIOLOGICAL QUALITY}

Microbial quality of beef burger was assessed through estimation of Enterobacteriaceae, Staphylococcus, proteolytic, lipolytic bacterial and total mould counts (tables II-VI) whereas microbial load could have been implicated for public hazard. Enterobacteriaceae, Staphylococcus, proteolytic, lipolytic bacteria and total mould counts of control samples were significantly higher $(\mathrm{p} \leq 0.05)$ than all treated samples and continued for the end of the experiment.

Addition of TEO and JO to beef burger formulation significantly minimized $(\mathrm{p} \leq 0.05)$ microbial load of examined samples than control one. At 0 , and $3 \mathrm{~d}$ no significant difference could be established between treated samples for each examined bacterial group with expect ion of Staphylococcus count, where $0.06 \%$ TEO treated samples $(2.3 \pm 0.083)$ were significantly lower than JO

Table II. Mean Enterobacteriaceae count log10 cfu $/ g$ of examined samples. (Control de Enterobacteriaceae en $\log _{10}$ de CFU/g de muestra examinada).

\begin{tabular}{cccccc}
\hline $\begin{array}{l}\text { Period } \\
\text { (days) }\end{array}$ & Control & Thyme 0.02\% & $\begin{array}{c}\text { Treatment } \\
\text { Thyme 0.04\% }\end{array}$ & Thyme 0.06\% & Jojoba 0.1\% \\
\hline 0 & $3.00 \pm 0.108^{\mathrm{a}}$ & $2.69 \pm 0.097^{\mathrm{b}}$ & $2.65 \pm 0.095^{\mathrm{b}}$ & $2.65 \pm 0.095^{\mathrm{b}}$ & $2.52 \pm 0.091^{\mathrm{b}}$ \\
3 & $4.47 \pm 0.161^{\mathrm{a}}$ & $2.65 \pm .095^{\mathrm{bc}}$ & $2.69 \pm 0.097^{\mathrm{b}}$ & $2.47 \pm 0.089^{\mathrm{c}}$ & $2.65 \pm 0.095^{\mathrm{bc}}$ \\
6 & $5.77 \pm 0.208^{\mathrm{a}}$ & $3.00 \pm 0.108^{\mathrm{c}}$ & $2.65 \pm 0.095^{\mathrm{d}}$ & $2.48 \pm 0.089^{\mathrm{d}}$ & $3.90 \pm 0.140^{\mathrm{b}}$ \\
9 & $7.30 \pm 0.263^{\mathrm{a}}$ & $3.90 \pm 0.140^{\mathrm{c}}$ & $3.00 \pm 0.108^{\mathrm{d}}$ & $2.48 \pm 0.089^{\mathrm{e}}$ & $4.30 \pm 0.155^{\mathrm{b}}$ \\
12 & $8.90 \pm 0.320^{\mathrm{a}}$ & $4.69 \pm 0.169^{\mathrm{c}}$ & $4.30 \pm 0.155^{\mathrm{d}}$ & $3.00 \pm 0.108^{\mathrm{e}}$ & $5.32 \pm 0.192^{\mathrm{b}}$ \\
15 & - & $6.30 \pm 0.227^{\mathrm{b}}$ & $4.85 \pm 0.175^{\mathrm{c}}$ & $3.30 \pm 0.119^{\mathrm{d}}$ & $7.24 \pm 0.282^{\mathrm{a}}$ \\
\hline
\end{tabular}

abIn a row, means with similar letters are not significantly different at $p \leq 0.05$.

Each value represents the mean \pm S.D. 
KASSEM, ATTA-ALLAAND ALI

Table III. Mean staphylococci count log $10 \mathrm{cfu} / \mathrm{g}$ of examined samples. (Control de estafilococos en $\log _{10}$ de CFU/g de muestra examinada).

\begin{tabular}{cccccc}
\hline $\begin{array}{l}\text { Period } \\
\text { (days) }\end{array}$ & Control & Thyme 0.02\% & $\begin{array}{c}\text { Treatment } \\
\text { Thyme 0.04\% }\end{array}$ & Thyme 0.06\% & Jojoba 0.1\% \\
\hline 0 & $2.84 \pm 0.102^{\mathrm{a}}$ & $2.40 \pm 0.086^{\mathrm{bc}}$ & $2.41 \pm 0.087^{\mathrm{bc}}$ & $2.30 \pm 0.083^{\mathrm{c}}$ & $2.48 \pm 0.089^{\mathrm{b}}$ \\
3 & $3.69 \pm 0.133^{\mathrm{a}}$ & $2.48 \pm 0.089^{\mathrm{c}}$ & $2.47 \pm 0.089^{\mathrm{c}}$ & $2.30 \pm 0.083^{\mathrm{c}}$ & $2.78 \pm 0.100^{\mathrm{b}}$ \\
6 & $4.48 \pm 0.161^{\mathrm{a}}$ & $2.95 \pm 0.106^{\mathrm{c}}$ & $2.60 \pm 0.094^{\mathrm{d}}$ & $2.00 \pm 0.072^{\mathrm{e}}$ & $3.47 \pm 0.125^{\mathrm{b}}$ \\
9 & $6.30 \pm 0.227^{\mathrm{a}}$ & $3.00 \pm 0.108^{\mathrm{c}}$ & $2.70 \pm 0.097^{\mathrm{d}}$ & $2.30 \pm 0.083^{\mathrm{e}}$ & $3.95 \pm 0.142^{\mathrm{b}}$ \\
12 & $6.95 \pm 0.250^{\mathrm{a}}$ & $4.30 \pm 0.155^{\mathrm{b}}$ & $2.84 \pm 0.102^{\mathrm{c}}$ & $2.48 \pm 0.100^{\mathrm{d}}$ & $4.47 \pm 0.161^{\mathrm{b}}$ \\
15 & - & $5.00 \pm 0.180^{\mathrm{c}}$ & $3.48 \pm 0.125^{\mathrm{d}}$ & $3.00 \pm 0.108^{\mathrm{e}}$ & $6.30 \pm 0.227^{\mathrm{b}}$
\end{tabular}

${ }^{a b}$ In a row, means with similar letters are not significantly different at $p \leq 0.05$.

Each value represents the mean \pm S.D.

$(2.78 \pm 0.1)$ treated samples (Mohsenzadeh,M 2007). After six days of storage, $0.06 \%$ TEO treat beef burger revealed the significant lowest count for Enterobacteriaceae, Staphylococcus, proteolytic, lipolytic bacteria and total mould counts followed by $0.04 \%$ TEO treated one and continued for two weeks of refrigerated storage. Meanwhile, microbial load of samples treated with JO was significantly higher than that of samples treated with different concentration of TEO. These results may emphasize the antimicrobial activity of phenolic compounds in TEO mainly thymol and carvacrol in (Cosentino et al., 1999; Peñalver et al., 2005; Šegviæ et al., 2006 and Viuda et al., 2008).

Considering the antimicrobial effects of TEO added in burger formulation the data given in tables (II-VI) indicated that 0.04 and $0.06 \%$ concentrations significantly minimized microbial load than control, $0.02 \%$ thyme and JO treated samples. As 0.04 and $0.06 \%$ thyme treated samples revealed 4.6 , $4.11,3.09,2.22,2.3$ and 5.9, 4.47, 3.39, 3.4 and $3.3 \log \mathrm{cfu} / \mathrm{g}$ respectively reduction in counts of Enterobacteriaceae, Staphylococcus, proteolytic, lipolytic bacterial and

Table IV. Mean proteolytic count log10 cfu /g of examined samples. (Control de proteolíticos en $\log _{10}$ de CFU/g de muestra examinada).

\begin{tabular}{cccccc}
\hline $\begin{array}{l}\text { Period } \\
\text { (days) }\end{array}$ & Control & Thyme 0.02\% & $\begin{array}{c}\text { Treatment } \\
\text { Thyme 0.04\% }\end{array}$ & Thyme 0.06\% & Jojoba 0.1\% \\
\hline 0 & $3.77 \pm 0.136^{\mathrm{a}}$ & $2.48 \pm 0.089^{\mathrm{b}}$ & $2.48 \pm 0.089^{\mathrm{b}}$ & $2.48 \pm 0.089^{\mathrm{b}}$ & $2.47 \pm 0.089^{\mathrm{b}}$ \\
3 & $3.77 \pm 0.136^{\mathrm{a}}$ & $2.30 \pm 0.083^{\mathrm{b}}$ & $2.48 \pm 0.089^{\mathrm{b}}$ & $2.30 \pm 0.083^{\mathrm{b}}$ & $2.47 \pm 0.089^{\mathrm{b}}$ \\
6 & $4.00 \pm 0.144^{\mathrm{a}}$ & $2.69 \pm 0.097^{\mathrm{c}}$ & $2.30 \pm 0.083^{\mathrm{d}}$ & $2.69 \pm 0.097^{\mathrm{c}}$ & $3.60 \pm 0.130^{\mathrm{b}}$ \\
9 & $4.47 \pm 0.161^{\mathrm{a}}$ & $3.30 \pm 0.119^{\mathrm{c}}$ & $2.80 \pm 0.101^{\mathrm{d}}$ & $2.84 \pm 0.102^{\mathrm{d}}$ & $3.95 \pm 0.142^{\mathrm{b}}$ \\
12 & $6.39 \pm 0.230^{\mathrm{a}}$ & $4.00 \pm 0.144^{\mathrm{c}}$ & $3.30 \pm 0.119^{\mathrm{d}}$ & $3.00 \pm 0.108^{\mathrm{e}}$ & $4.30 \pm 0.155^{\mathrm{b}}$ \\
15 & - & $5.30 \pm 0.191^{\mathrm{b}}$ & $3.95 \pm 0.142^{\mathrm{c}}$ & $3.30 \pm 0.119^{\mathrm{d}}$ & $5.60 \pm 0.202^{\mathrm{a}}$ \\
\hline
\end{tabular}

${ }^{a b}$ In a row, means with similar letters are not significantly different at $p \leq 0.05$.

Each value represents the mean \pm S.D.

Archivos de zootecnia vol. 60, núm. 231, p. 792. 


\section{EFFECTS OF THYME ESSENTIAL OIL AND JOJOBA OIL ON BEEF BURGER QUALITY}

Table $\boldsymbol{V}$. Mean lipolytic count $\log 10 \mathrm{cfu} / \mathrm{g}$ of examined samples. (Control de lipolíticos en $\log _{10}$ de CFU/g de muestra examinada).

\begin{tabular}{cccccc}
\hline $\begin{array}{l}\text { Period } \\
\text { (days) }\end{array}$ & Control & Thyme 0.02\% & $\begin{array}{c}\text { Treatment } \\
\text { Thyme 0.04\% }\end{array}$ & Thyme 0.06\% & Jojoba 0.1\% \\
\hline 0 & $3.00 \pm 0.108^{\mathrm{a}}$ & $2.48 \pm 0.089^{\mathrm{b}}$ & $2.48 \pm 0.089^{\mathrm{b}}$ & $2.48 \pm 0.089^{\mathrm{b}}$ & $2.47 \pm 0.089^{\mathrm{b}}$ \\
3 & $3.30 \pm 0.119^{\mathrm{a}}$ & $2.48 \pm 0.089^{\mathrm{b}}$ & $2.48 \pm 0.089^{\mathrm{b}}$ & $2.00 \pm 0.072^{\mathrm{c}}$ & $2.47 \pm 0.089^{\mathrm{b}}$ \\
6 & $3.95 \pm 0.142^{\mathrm{a}}$ & $2.78 \pm 0.100^{\mathrm{c}}$ & $2.30 \pm 0.083^{\mathrm{d}}$ & $2.30 \pm 0.083^{\mathrm{d}}$ & $3.47 \pm 0.125^{\mathrm{b}}$ \\
9 & $4.00 \pm 0.144^{\mathrm{a}}$ & $3.30 \pm 0.119^{\mathrm{c}}$ & $2.70 \pm 0.097^{\mathrm{d}}$ & $2.30 \pm 0.083^{\mathrm{e}}$ & $3.69 \pm 0.133^{\mathrm{b}}$ \\
12 & $6.00 \pm 0.216^{\mathrm{a}}$ & $3.95 \pm 0.142^{\mathrm{b}}$ & $3.78 \pm 0.136^{\mathrm{b}}$ & $2.60 \pm 0.094^{\mathrm{c}}$ & $3.69 \pm 0.133^{\mathrm{b}}$ \\
15 & - & $5.00 \pm 0.180^{\mathrm{a}}$ & $3.78 \pm 0.136^{\mathrm{c}}$ & $3.0 \pm 0.108^{\mathrm{d}}$ & $4.30 \pm 0.155^{\mathrm{b}}$
\end{tabular}

ab In a row, means with similar letters are not significantly different at $p \leq 0.05$.

Each value represents the mean \pm S.D.

total mould counts than control samples respectively at $12^{\text {th }}$ day of storage. These obtained result confirmed the possibility of using thyme essential oils in meat products to prevent the growth of either spoilage and pathogenic bacteria and extend their shelf-life.

\section{CONCLUSION}

From the obtained results, it could be concluded that addition of TEO to beef burger formulation at concentration of 0.04 and $0.06 \%$ not only minimize lipid oxidation but also improved its sensory characteristics and enhanced the wholesomeness of the product during two weeks of refrigerated storage. JO incorporation in beef burger formulation also showed lower TBA-value and microbial load than control samples. Furthermore, during refrigerated storage shelf life of $0.02 \%$ TEO and jojba $\mathrm{O}$ treated samples was extended for three days more than control. While beef burger treated with 0.04 and $0.06 \%$ TEO showed five days more than Control burger. With superior quality for TEO $0.06 \%$ treated burger at the end of storage time.

Table VI. Mean total mould count log10 cfu /g of examined samples. (Control de hongos en $\log _{10}$ de CFU/g de muestra examinada).

\begin{tabular}{cccccc}
\hline $\begin{array}{l}\text { Period } \\
\text { (days) }\end{array}$ & Control & Thyme 0.02\% & $\begin{array}{c}\text { Treatment } \\
\text { Thyme 0.04\% }\end{array}$ & Thyme 0.06\% & Jojoba 0.1\% \\
\hline 0 & $2.99 \pm 0.108^{\mathrm{a}}$ & $2.69 \pm 0.097^{\mathrm{b}}$ & $2.70 \pm 0.097^{\mathrm{b}}$ & $2.69 \pm 0.097^{\mathrm{b}}$ & $2.70 \pm 0.097^{\mathrm{b}}$ \\
3 & $3.95 \pm 0.142^{\mathrm{a}}$ & $2.69 \pm 0.097^{\mathrm{b}}$ & $2.70 \pm 0.097^{\mathrm{b}}$ & $2.48 \pm 0.022^{\mathrm{b}}$ & $2.70 \pm 0.097^{\mathrm{b}}$ \\
6 & $4.30 \pm 0.155^{\mathrm{a}}$ & $3.30 \pm 0.119^{\mathrm{c}}$ & $2.78 \pm 0.100^{\mathrm{d}}$ & $2.48 \pm 0.089^{\mathrm{e}}$ & $3.90 \pm 0.140^{\mathrm{b}}$ \\
9 & $5.69 \pm 0.205^{\mathrm{a}}$ & $3.85 \pm 0.139^{\mathrm{c}}$ & $3.95 \pm 0.142^{\mathrm{c}}$ & $2.69 \pm 0.097^{\mathrm{d}}$ & $4.60 \pm 0.166^{\mathrm{b}}$ \\
12 & $6.60 \pm 0.238^{\mathrm{a}}$ & $5.00 \pm 0.180^{\mathrm{c}}$ & $4.30 \pm 0.155^{\mathrm{d}}$ & $3.30 \pm 0.119^{\mathrm{e}}$ & $6.20 \pm 0.223^{\mathrm{b}}$ \\
15 & - & $6.60 \pm 0.238^{\mathrm{b}}$ & $4.95 \pm 0.178^{\mathrm{c}}$ & $3.85 \pm 0.139^{\mathrm{d}}$ & $7.30 \pm 0.263^{\mathrm{b}}$ \\
\hline
\end{tabular}

${ }^{a b}$ In a row, means with similar letters are not significantly different at $p \leq 0.05$.

Each value represents the mean \pm S.D. 


\section{KASSEM, ATTA-ALLAAND ALI}

\section{REFERENCES}

Akgül, A. and Kivanç, M. 1988. Inhibitory effects of selected Turkish spices and oregano components on some food borne fungi. Int. J. Food Microbiol., 6: 263-268.

Amarowicz, R., Egarska, Z., Rafalowski, R., Pegg R.B., Karamac', M. and Ska, A.K. 2009. Antioxidant activity and free radical-scavenging capacity of ethanolic extracts of thyme, oregano, and marjoram. Eur. J. Lipid Sci. Tech., 111: 1111 1117.

AMSA. 1995. American Meat Science Association. Research guidelines for cookery, sensory evaluation and instrumental tenderness of fresh meat. National Livestock and Meat Board. Chicago, IL.

APHA. 1992. American Public Health Association. Compendium of methods for the microbial examination of food. $3^{\text {rd }}$ Ed. American Public Health Association. Washington, DC. USA

Arora, D.S. and Kaur, J. 1999. Antimicrobial activity of spices. Int. J. Antimicrob. Ag., 12: 257-262.

Cosentino, S., Tuberoso, C.I.G., Pisano, B., Satta, M., Masia, V., Arzed, E. and Palmas, F. 1999. In vitro antimicrobial activity and chemical composition of Sardinian Thymus essential oils. Lett. Appl. Microbiol., 29: 130-135.

Djenane, D., Martinez, L., Sanchez-Escalante, A. and Beltran, J.A. 2004. Antioxidant effect of carnosine and carnitine in fresh beef steaks stored under modified atmosphere. J. Food Chem., 85: 453-459.

Dorman, H.J.D. and Deans, S.G. 2000. Antimicrobial agents from plants: antibacterial activity of plant volatile oils. J. Appl. Microbiol., 88: 308

Duncan, D.B. 1955. Multiple range and multiple $F$ test. Biometrics, 11: 1-42.

Dzudie, T., Kouebou, C.P., Essia-Ngang, J.J. and Mbofung, C.M.F. 2004. Lipid sources and essential oils effects on quality and stability of beef patties. J. Food Eng., 65: 67-72.

Elgayyar, M., Draughon, F.A., Golden, D.A. and Mount, J.R. 2001. Antimicrobial activity of essential oils from plants against selected pathogenic and saprophytic microorganisms. J. Food Protect., 64: 1019-1024.

ESS. 1991. Egyptian standard specification. Egyptian standard specification for frozen burger (1688). Egyptian organization for standardization and quality control. Egypt.
FAO. 1986. Food and Agriculture organization. Manuals of food quality control. 8. Food analysis. Rome. Italy.

Jones, F.A. 1996. Herbs-useful plants. Their role in history and today. Eur. J. Gastroen. Hepat., 8: 1227-1231.

Gulluce, M., Sokmen, M. Daferera, D., Agar, G., Ozkan, H., Kartal, N., Polissiou, M., Sokmen, A and Sahin, F. 2003. In vitro antibacterial, antifungal, and antioxidant activities of the essential oil and methanol extracts of herbal parts and callus cultures of Satureja hortensis L. J. Agr. Food Chem., 51: 3958-3965.

Kalemba, D. and Kunicka, A. 2003. Antibacterial and antifungal properties of essential oils. Curr Med. Chem., 10: 813-29.

Kalscheuer, R., Stöveken,T., Luftmann, H., Malkus, U., Reichelt, R. and Steinbüchel, A. 2006. Neutral lipid biosynthesis in engineered Escherichia coli: jojoba oil-like wax esters and fatty acid butyl esters. Appl. Environ. Microb., 72: 13731379.

Kim, J., Marshall, M.R. and Wei, C. 1995. Antimicrobial properties of some essential oils components against five food- born pathogens. J. Agr. Food Chem., 43: 2839-2845.

Lacroix, M., Smoragicz, W., Pazdernik, L., Kone, M.I. and Krzystyniak, K. 1997. Prevention of lipid radiolysis by natural antioxidants from rose marry and thyme. Food Res. Int., 30: 457-462.

Lagouri, V. and Nisteropoulou, E. 2009. Antioxidant properties of $O$. onites, T. vulgaris and $O$. basilicum species grown in greece and their total phenol and rosmarinic acid content. J. Food Lipids, 16: 484-498.

Lawless, J. 1995. The illustrated encyclopedia of essential oils. Element books Ltd. Shaftesbury. UK.

Lis-Ba, M. and Deans, S.G. 1997. Bioactivity of selected plant essential oils Listeria monocytogenes. Appl. Microbiol., 82: 759-762.

Lopez-Malo, A., Alzamora, S.M. and Guerrero, S.S. 2000. Natural antimicrobial from plants. In: Minimally process food and vegetables. Fundamental aspects and applications. Ed. Alzamora, S.M. Tapia, M.S. and Lopez-Malo, A. Aspen Publishers, Inc. Gaithersburg. pp. 263.

Mejlholm, O. and Dalgaard, P. 2002. Antimicrobial effect of essential oils on the seafood spoilage 


\section{EFFECTS OF THYME ESSENTIAL OIL AND JOJOBA OIL ON BEEF BURGER QUALITY}

micro-organisms in liquid media and fish products. Lett. Appl. Microbiol., 34: 27-31.

Mishra, A.K. and Dube, N.K. 1994. Evaluation of some essential oils for their toxicity against fungi causing deterioration of stored food commodities. Appl. Environ. Microb., 60: 11011105.

Miwa, T.K. 1971. Jojoba oil wax esters and derived fatty acids and alcohols: gas chromatographic analyses. J. Am. Oil Chem. Soc., 48: 259-264.

Mohsenzadeh,-M. 2007. Evaluation of antibacterial activity of selected Iranian essential oils against Staphylococcus aureus and Escherichia coli in nutrient broth medium. Pakistan J. Biol. Sci., 10: 3693-3697.

Nguefack, J., Dongmo, J.B., Dakole, C.D., Leth, V., Vismer, H.F., Torp, J. and Nkengfack, A.E. 2009. Food preservative potential of essential oils and fractions from Cymbopogon citratus, Ocimum gratissimum and Thymus vulgaris against mycotoxigenic fungi. Int. J. Food Microbiol., 131: 151-156.

Nychas, G.J.E. and Tassou, C.C. 2000. Tradition preservatives-oils and spices. In: Encyclopedia of food microbiology. Ed. Robinson, R.K., Batt, C.A. and Patel, P.D. Academic Press. San Diego. pp.1717-1722.

Peñalver, P., Huerta, B., Borge, C., Astorga, R., Romero, R. and Perea, A. 2005. Antimicrobial activity of five essential oils against animal origin strains of the Enterobacteriaceae family APMIS, 113: 1-6.

Pikul, J., Leszeznski, D.E. and Kummerow, F. 1983. Elimination of samples autooxidation by butylated hydroxytoluene additions before thiobarbituric acid assay for malonaldehyde in fat from chicken meat. J. Agr. Food Chem., 31: 1338.

Reynolds, S. 1996. Martindale. The extra Pharmacopoeia $31^{\text {st }}$ ed. Royal Pharmaceutical Society. London.

Rhee, K.S. 1989. Chemistry of meat flavour. In: Flavour chemistry of lipid food. Minand Smouse. Champain. pp. 462.

Saguy, S., Shani, A., Weinberg, P. and Garti, N. 1996. Utilization of jojoba oil for deep-fat frying of food. Lebensmittle Wiss. Technol., 29: 537577.

Salgm, U. 2007. Extraction of jojoba seed oil using super critical $\mathrm{CO}_{2}+$ ethanol mixture in green and high-tech separation process. J. Supercrit. fluids. 39: 330-337. http://www.sciencedirect. com/science (01/10/10).

SAS. 1995. Statistical Analysis System. SAS User's Guide Statistics. SAS Institute Inc. Cary, NC.

Šegviæ, K.M., Kosalec, I., Masteliæ, J., Piecková, E. and Pepeljnak, S. 2006. Antifungal activity of thyme (Thymus vulgaris L.) essential oil and thymol against moulds from damp dwellings. Lett. Appl. Microbiol., 10: 1472-765.

Senatore, F. 1996. Influence of harvesting time on yield and composition of the essential oil of thyme growing wild in Campania (south Italy). $J$. Agr. Food Chem., 44: 1327-32.

Singh, R.P. 1996. Scientific principles of shelf life evaluation. In: Shelf life evaluation of food. Shapmanand Hall. Sufflok. UK. pp. 3-26.

Skerget, M., Kotnik, P., Hadolin, M., Hras, A.R., Simonic, M. and Knez, Z. 2005. Phenols, proanthocyanidins, flavones and flavonols in some plant materials and their antioxidant activities. Food Chem., 89: 191-198.

Smith-Palmer, A., Stewart, J. and Fyfe, L. 1998. Antimicrobial properties of plant essential oils and essences against five important food- born pathogens. Lett. Appl. Microbiol., 26: 118-22.

Sofos, J.N., Beuchat, L.R., Davidson, P.M. and Johnson, E.A. 1998. Naturally occurring antimicrobials in food. Agric. Sci. Tech. Report, $n^{\circ}$ 132. Ames. lowa. USA.

Soliman, K.M. and Badeae, R.I. 2002. Effect of oil extracted from some medicinal plants on different mycotoxigenic fungi. Food Chem. Toxicol., 40: 1669-1675.

Spencer, J.F.T. and De Spencer, A.L.R. 2001. Food microbiology protocols. $1^{\text {st }}$ ed. Humana Press Totowa. New Jersey.

Stahl-Biskup, E. 1991. The chemical composition of thyme oils. A review of the literature 1960-89. J. Essent. Oil Res., 3: 61-82.

Viuda, M.M., Ruiz, N.Y., Fernandez, L.J. and Perez, A.J.A. 2008. Antibacterial activity of different essential oils obtained from spices widely used in Mediterranean diet. Int. J. Food Sci. Technol., 43: 526-531.

Wisniak, J. 1994. Potential uses of jojoba oil and meal. Ind. Crop. Prod., 3: 43-68.

Wojdylo, A., Oszmiansk, J. and Czemerys, R. 2007. Antioxidant activity and phenolic compounds in 32 selected herbs. Food Chem., 105: 940-949. 